Pegem Journal of Education \& Instruction, 3(3), 2013, 01-10

Pegem Eğitim ve Öğretim Dergisi, 3(3), 2013, 01-10

www.pegegog.net

WEB TABANLI DINLEDiĞiNi ANLAMA TESTININ GEÇERLiK VE GÜVENIRLIK ÇALIŞMASI*

\title{
VALIDITY AND RELIABILITY STUDY OF THE WEB BASED LISTENING COMPREHENSION TEST
}

\author{
M. Bahaddin ACAT ${ }^{* *}$, Hilmi DEMIRAL, Mehmet Fatih KAYA
}

Eskişehir Osmangazi Üniversitesi Eğitim Fakültesi, Eskişehir/Türkiye

Özet

Bu çalışmanın amacı, ilköğretim 5. sınıf öğrencilerine yönelik web tabanlı olarak hazırlanan dinlediğini anlama testinin geçerlik ve güvenirlik çalışmalarını yapmaktır. Testin kapsam geçerliği ilköğretim Türkçe Dersi Öğretim Programı́nda yer alan 5. sınıf dinleme kazanımları içinden toplam 36 kazanımdan 27 kazanım ile sağlanmıştır. Ardından bu kazanımların kazanılıp kazanılmadığını ölçebilecek yapılar hazırlanmıştır. Başta 56 madde olarak hazırlanan testin kapsam geçerliği için Türkçe eğitimi alanında çalışan iki uzman ve ölçme ve değerlendirme alanında çalş̧an iki uzman olmak üzere toplam dört uzmanın görüşüne başvurulmuş ve gerekli düzeltmeler sonrasında ön uygulamalar yapılmıştır. Karşılaşılan hatalar ve eksiklikler yine uzmanların görüşleri doğrultusunda giderilerek testte nihai olarak 41 madde bırakılmıştır. Testin iç tutarlık anlamındaki güvenirliğini hesaplamak için Cronbach Alfa ve KR20 güvenirlik katsayıları hesaplanmış ve her iki katsayı da .77 olarak bulunmuştur. Bununla birlikte iki yarı yöntemiyle hesaplanan güvenirlik katsayısı Spearman-Brown düzeltmesinin ardından .80 olarak elde edilmiştir. Bu değerler testin güvenilir olduğunu göstermektedir. Ayrıca testin uygulandığı web tabanlı sistemin kullanımı esnasında öğrencilerin daha dikkatli ve güdülenmiş bir şekilde süreçte yer aldıkları gözlenmiştir. Buna göre web tabanlı ortamların dil becerilerini ölçme ve değerlendirme süreçlerinde kullanılabilir olduğu söylenebilir.

Anahtar kelimeler: Dinlediğini anlama, web tabanlı dinleme, dinlediğini anlama testi, Türkçe öğretimi.

\section{Abstract}

The purpose of this study is to examine validity and reliability of the web based test designed to measure listening skills of the 5th graders. The test's content validity supplied 27 of 36 listening objectives described in the curriculum for the 5th graders' Turkish course. After, the constructs were prepared for measuring if the students can gain the listening objectives. Firstly 56 items were prepared. Then two experts working on the fields of Turkish instruction and two experts working on the fields of measurement and evaluation were asked for their opinion about content validity. After making necessary corrections proposed by the experts, eventually, 41 items were left in the test and pilot studies were conducted. KR-20 and Cronbach Alpha coefficients were estimated both being as . 77 in an attempt to determine internal consistency of the test. The reliability coefficient calculated by means of

Bu çalışma, Eskişehir Osmangazi Üniversitesi Bilimsel Araştırma Projeleri Komisyonu tarafından desteklenen 201219A107 nolu proje dâhilinde; hazırlanan "ilköğretim 5. Sınıf Öğrencilerinin Dinleme Becerilerinin Web Tabanlı Bir Sistem Yardımıyla Ölçülmesi” başıklı yüksek lisans tezi verilerinden hazırlanmıştır. Aynı zamanda bu çalışma 12-14 Eylül 2012 tarihleri arasında Marmara Üniversitesi Atatürk Eğitim Fakültesi tarafından İstanbul'da düzenlenen "21. Ulusal Eğitim Bilimleri Kongresi"nde sunulan sözlü bildirinin geliştirilmiş şeklidir.

** Yazar: bacat@ogu.edu.tr 
Spearman-Brown prophecy formula was found as .80 . Such findings point out that the test is reliable. It was also observed during the study that students tend to have higher motivation and concentration level when they engage in web based systems. Therefore, it could be said that web-based environments could be used for measuring and evaluating language skills.

Keywords: Listening comprehension, web based listening, listening comprehension test, Turkish instruction.

\section{Giriş}

Bireyin çevresiyle etkili bir uyum halinde olması, içinde bulunduğu şartları iyi değerlendirmesi ve çevresiyle iyi ilişkiler kurabilmesi bakımından anlama eğitiminin (Gül, 1998), buna bağı olarak da dinleme eğitiminin önemi büyüktür. Hayatın her alanında kurulan ilişkileri içine alan dinleme beceri ve alışkanlığı, okul öncesi dönemde doğal biçimde kendiliğinden ve gelişigüzel edinilmesine rağmen insanları dinlediklerini tam, doğru ve eksiksiz anlayan, ayırt eden ve değerlendiren kimseler haline getirmemektedir (Yangın, 1999). Bu durumun getirdiği bir sonuç olarak, bireylerin dinleme becerilerinin ilköğretim çağlarında iken geliştirilmesi gerekmektedir. Hazırlanan öğretim programlarının bu gereklilikleri göz önüne alınarak hazırlanması ön plana çıkmaktadır. Yıllar boyu Batı eğitim alan yazınında dinleme, konuşma ve yazmadan sonra arka planda kalmış ve "neglected skill" yani "ihmal/göz ardı edilmiş beceri" olarak tanımlanmış (Çifçi, 2006; Giri, 1998; Kavaliauskienė, 2008; Özbay, 2010) ve ülkemizde ilk defa 2005 yııında uygulamaya konulan Türkçe Dersi Öğretim Programı (TDÖP)'nda ayrıntılı bir şekilde yer almıştır (MEB, 2005).

Gelişen teknolojinin getirdiği yenilikler olan bilgisayar ve internet hayatımızın her alanında yerini alırken dil eğitimi, öğretimi, ölçülmesi ve değerlendirilmesi konularında pek çok yeniliği, değişimi ve kolaylığı beraberinde getirmiştir. Bilgisayar tabanlı testler psikoloji ve matematik gibi alanlarda kullanılırken (Sawaki, 2001) dil ve dil becerilerinin eğitimi, öğretimi, ölçülmesi ve değerlendirilmesi alanlarında Türkiye'de hem uygulanan öğretim programları bağlamında hem de akademik çalışma alanında kullanıldığını görmemekteyiz. Özellikle yurtdışında yapılan çalışmalar incelendiğinde son yıllarda bilgisayar ve web tabanlı olarak hazırlanan dil becerilerini değerlendirme testlerinin kullanımının arttığı ve yaygınlaştığı görülmektedir. Bununla birlikte bilgisayar ortamına aktarılmış testlerin, geleneksel kâğıt testlere nazaran potansiyel ve olası etkilerini inceleyen araştırmaların sayısı sınırıdır (Al-Amri, 2008; Chalhoub-Deville ve Deville, 1999). Her iki test şekli arasında anlamlı farklılıklar olduğunu gösteren araştırmaların yanında (Choi, Kim ve Boo, 2003; Pomplun, Frey ve Becker, 2002), böyle bir farkın söz konusu olmadığını gösteren araştırmalar da mevcuttur (Aybek, 2012; Boo, 1997; Bugbee, 1996; Whitworth, 2001). Bununla birlikte bilgisayarların sağladığı avantajlar iyi bilinmekte ve gittikçe önemi daha da artmaktadır. Bu süreçte hazırlanan ortama kolay ulaşılabilme, içerdiği materyalin daha etkili ve etkileşimli bir şekilde hazırlanabilmesi vb. kolaylıklar sağladığı gibi test hazırlayıcılara alanlarında yeniliğe liderlik etme ve kendi ürettiklerini geliştirme fırsatı verirken bir yandan da testin uygulanması esnasında yönetim şartlarını standartlaştırması, testin uygulanacağı kişi sayısı ne kadar çok olursa olsun uygulayıcıya bütün katılımcıların aynı şartlarda süreçte yer almalarını sağlaması bilgisayar ve web tabanlı ortamların beraberinde getirdiği faydalardandır (Al-Amri, 2008; Alderson, 2000; Brown, 1997; Oral, 2005). Bunların yanında bilgisayar ve web tabanlı ortamların uygun yazılımın hazırlanamaması, donanımın temin edilememesi, testler için gereken standartların sağlanamaması (ekran çözünürlüğü, ekran büyüklüğü, resim kalitesi, ses kalitesi vb.) ve uygulama esnasında donanım ve yazılım sorunlarının yaşanması gibi dezavantajları da bulunmaktadır (Bugbee, 1996; Ergün, 2002; Mead ve Drasgow, 1993; PISA, 2010; Smith ve Caputi, 2005). Bilgisayar ve web tabanlı sistemlerle ilgili olarak Johnson ve Green (2004), eğer bilgisayar teknolojisinin var olduğu iddia edilen potansiyeli ortaya konursa, en az kâğıt ve kaleme dayalı değerlendirmenin geçerlik ve güvenirliğine ulaşacağı ve onun yerini alacağııı savunmaktadır.

Türkiye'de dinleme ile ilgili alan yazın incelendiğinde web tabanlı sistemlerin kullanıldığı çalışmalara rastlanmamaktadır. Bu açıdan bakıldı̆ıında bu çalışmanın genel olarak Türkçe eğitiminde web tabanlı 
sistemlerin kullanılabilirliği açısından önemli bir katkı sağlayacağı söylenebilir. Özelde ise ilköğretim öğrencilerinin dinleme becerilerinin web tabanlı bir sistem yardımıyla ölçülmesi temeline dayanan bu çalışmanın dinleme becerilerinin geliştirilmesi, ölçülmesi ve değerlendirilmesinde uygulayıcı olan öğretmenlere ve ileriki dönemde bu konuda çalışmalar yapacak olan araştırmacılara model olacağı düşünülmektedir. Bu doğrultuda hazırlanan bu çalışma, ilköğretim 5. sınıf öğrencilerinin dinlediğini anlama becerilerini belirmeye dönük bir ölçme aracı geliştirmeyi amaçlamaktadır.

\section{Yöntem}

\section{Çalışma Grubu}

Çalışma grubuna 2011-2012 öğretim yılında, Eskişehir il merkezinde yer alan kamu ilköğretim okullarının 5. sınıflarında öğrenim gören 8255 öğrenci içerisinden seçilen 605 öğrenci katılmıştır. Çalışma grubu için okulların belirlenmesinde, bir önceki öğretim yılı sonunda yapılan 6. sınıf "Seviye Belirleme Sınavı (SBS)"na göre yapılan başarı sıralaması göz önüne alınmıştır. Buna göre en yüksek ve en düşük okulların puanları arasındaki fark üçe bölünmüş ve okullar sabit aralıklarla "düşük, orta ve yüksek" olarak üç gruba ayrıımıştır. Bununla birlikte çalışmanın yapılacağı öğretim yılında bilgisayar dersleri kaldırımış ve bazı okullarda bilgisayar laboratuvarları kapatılmıştır. Dolayısıyla başarı sıralamasına göre oluşturulan gruplardan bilgisayar laboratuvarı olan okullar belirlenmiş ve 605 öğrenci seçilmiştir. Oluşturulan çalışma grubunun, testin içeriğinin, testin yapı ve kapsam geçerliğinin uygunluğu için Türkçe eğitimi alanında çalışan iki uzman ve ölçme ve değerlendirme alanında çalışan iki uzman olmak üzere toplam dört uzmanın görüşü alınmıştır.

\section{Test Geliştirme ve Uygulama Süreci}

Dinlediğini Anlama Testi, ilköğretim 5. sınıf öğrencilerinin dinlediğini anlama becerisinin ne ölçüde kazanıldığının belirlenebilmesi için hazırlanmışır. Testin kapsam geçerliliği, ilköğretim Türkçe Dersi Öğretim Programı'nda yer alan 5. sınıf dinleme kazanımları ile oluşturulan belirtke tablosu yardımıyla ve danışılan uzmanların dönütleriyle sağlanmıştır. Programdaki toplam 36 kazanımdan 9 kazanımın ölçülmesinin tek yolunun uzun süreli gözlem olduğu tespit edildiğinden, geri kalan 27 kazanımın ölçülmesine yönelik yapılar oluşturulmuştur. Hazırlanan belirtke tablosu yardımıyla testte kullanılacak metin ve cümlelerin seçiminde; ilgili yaş döneminin özellikleri göz önünde bulundurularak metin ve cümlelerin kısa, açık, anlaşııı olmasına, mümkün olduğunca farklı metin türlerinin kullanılmasına ve kazanılması gereken farklı değerleri (örneğin; çevre duyarıı̆ı̆ı, birlik-beraberlik, vatan sevgisi) içeren metinler olmasına dikkat edilmiştir. Bu sayede testin kapsam geçerliliği için Türkçe eğitimi alanında çalışan iki uzman ve ölçme ve değerlendirme alanında çalışan iki uzmanın görüşlerine göre hazırlanan metinlerin içeriği, uzunluğu, dinleme sürelerinin yeterliliği ve uygunluğu ve karşılık geldiği kazanımla örtüşüp örtüşmediği konularında başvurulmuştur. Çünkü kapsam geçerliği, "konuları ve yoklanacak davranışları belli olan başarı testleri için çok daha önemlidir" (Büyüköztürk, 2010: 168). Uzmanlardan gelen dönütler doğrultusunda düzeltmeler yapılarak ön uygulamalara geçilmiştir. Birer hafta aralıkla üç kez ön uygulama yapılmış, her seferinde karşılaşılan hatalar ve görülen eksiklikler giderilerek web tabanlı sistem uygulanabilir hale getirilmiştir. Başta 56 madde olarak hazırlanan test hakkında uzmanlardan alınan dönütler ve ön uygulamalarda karşılaşılan hata ve eksiklikler sonucunda sorunlu madde, metin ve içerikler çıkarılarak kapsam geçerliğini etkilemeyecek şekilde nihaî olarak farklı soru tiplerinin (çoktan seçmeli, çoklu seçmeli, boşluk doldurma) yer aldığı 41 madde bırakılmıştır. Her bir doğru cevap "1" puandır. Testlerin uygulanacağı web tabanlı sisteme test ve içerikler yüklenerek cevaplamada her bir doğru cevap için " 1 ", yanlış cevap için "0" olarak veri tabanına kaydetmesi için gereken düzenlemeler yapılmışır.

Dinlediğini anlama testi, öğrencilere web ortamında uygulanmıştır. Bunun için bir web adresi üzerinde çevrimiçi ölçme sistemi geliştirilmiştir. Bu sistem sayfa sayfa hazırlanmış ve öğrencilerin sisteme giriş yapabilmeleri için her öğrenciye birer kod verilmiştir. Öğrenciler kendilerine verilen kodu ilgili alana (Ek 1) girdikten sonra testin yer aldığı sayfalara geçilebilmektedir. Öğrencilerin gerekli alanları 
doldurmaları zorunlu tutulmuş, aksi takdirde sistem tarafından uyarılmışlardır (Ek 2). Bu sayfaların doldurulmasından sonra gelen her sayfada seslendirilmiş bir metin/cümle ve onlara ait sorular yer almaktadır (Ek 3, Ek 4, Ek 5). Ancak bu sayfalara gelindiğinde medya oynatıcı yardımıyla metinlerin kendiliğinden oynamaları sağlanmış; dinlenenleri durdurma, geri alma, ileri sarma işlemlerini engellemek için "oynat, duraklat, durdur" düğmeleri kaldırılmıştır. Böylece metinlerin bir kez dinlenmesi otomatik olarak sağlanmıştır.

Uygulama süreci tamamen araştırmacının gözetiminde ve yaklaşık bir ders saati sürecinde gerçekleştirilmiştir. Öğrenciler ders saatlerinde araştırmacı tarafından bilgisayar laboratuvarına götürülmüş, her öğrenci bir bilgisayarı kullanacak şekilde oturtulmuştur. Bu süreçte kendilerine, uygulamayı dış etkenlerden bağımsız bir şekilde yapabilmeleri için birer kulaklık dağıtılmıştır.

\section{Bulgular}

Ölçmenin yapılabilmesi için hazırlanan araçların sahip olması gereken özelliklerden ikisi geçerlik ve güvenirliktir. Bir ölçeğin geçerliği, istenen özelliği ölçme ve diğer özelliklere karıştırmadan ne derece doğru ölçtüğüyle ilgilidir (Büyüköztürk vd., 2010; Özçelik, 2011). Kısacası ölçekler, ilgili olduğu alana, duruma, olaya, davranışa vs. uygun olmalıdır. Güvenirlik ise, bir ölçme aracının ölçtüğü özellikle ilgili gerçeğe yakın sonuçlar verdiğini savunabilmesi için, özelliği ölçülen varlık veya olayların bu özelliğinde bir değişme olmadıkça onları hep aynı sıraya koyan ölçüler vermelidir. Yani ölçme aracının ölçtüğü şeyi kararlı bir şekilde ölçmelidir (Özçelik, 2010). Buna göre güvenirliğin bir ölçme aracının ve dolayısıyla ölçme sonuçlarının tesadüfi hatalardan arınıklık derecesi (Bahar vd., 2010; Karasar, 2009) olduğu söylenebilir.

Testin iç tutarlık anlamındaki güvenirliğini hesaplamak için madde güçlükleri eşit olmadığından dolayı KR-20 güvenirlik katsayısı hesaplanmış ve 77 olarak bulunmuştur. Bununla birlikte test, tek ve çift maddeler olmak üzere iki yarıya ayrılmış ve iki yarı yöntemiyle hesaplanan güvenirlik katsayısı SpearmanBrown düzeltmesinin ardından .80 olarak elde edilmiştir. Bu değerler, testin oldukça güvenilir olduğunu göstermektedir.

Testin madde analizlerine bakıldığında (Tablo-1), maddelerin ayırt edicilik açısından uygun oldukları gözlenmiştir. Buna rağmen madde ayırt ediciliği .20'den küçük olan maddelerin testten çıkarılması; .20 ve .30 arasında olan maddelerinse yeniden yapılacak uygulama esnasında gözden geçirilmesi veya testten çıkarılması faydalı olacaktır (Erkuş, 2009).

\section{Sonuç ve Tartışma}

Araştırmanın amacı doğrultusunda ölçümlerin gerçeğe yakın olabilmesi için web üzerinde öğrencileri süreç içerisinde dinleme açısından rahatsı eden veya dikkatini dağıtan seslere ve gürültülere olabildiğince kapalı olabilmeleri için kulaklık dağıtılmış, her bir soruyu süre açısından kısıtlayabilecek ve verdikleri cevapları değiştirmelerini engelleyebilecek bir sistem hazırlanmıştır. Her öğrencinin bir kod yardımıyla girebildiği bu sisteme dinleme metin ve cümleleri bu sisteme aktarılarak uygulamalar gerçekleştirilmiştir.

Web tabanlı bir ortamda gerçekleştirilen bu çalışmanın uygulama sürecinde bazı durum ve sorunlarla karşılaşılmış ve bundan sonra yapılacak uygulama ve çalışmalara ışık tutabilmesi açısından bazı noktalara değinmek faydalı olacaktır. Süreç içerisinde karşılaşılan sorunlar okulların teknolojik ve internet altyapısıyla ilgili sorunlardır. Aynı anda 10, 15 veya 20 öğrencinin dolayısıyla bir o kadar bilgisayarın kullanımından dolayı internet bağlantısı yavaşladığından zaman zaman uygulama sürecinde öğrencilerin motivasyonlarının düşmesine neden olduğu gözlenmiştir. Bunun yanında kimi okullarda bilgisayarların eski olmasından kaynaklanan sorunlar yaşanmıştır. Süreç içerisinde bazı bilgisayarlarda kullanılan internet tarayıcılarının donması sonucu bazı ölçümler yarım kalmış veya -vakit sorunu yoksa- tekrar başlatılmıştır. Bir diğer sorun ise uygulama yapılan bazı okulların bilgisayar laboratuvarındaki tüm 
bilgisayarlar kulaklıkla ses aktarımında sıkıntı yaşanmışır. Bu sorun bir hoparlör yardımıyla cümle ve metinler sınıfa dinletilerek aşılmaya çalışıımışır. Teknik ve teknolojik sorunlardan dolayı ortaya çıkan eksik ve hatalı ölçümlerin verileri araştırma kapsamı dışında tutulmuştur.

Tablo 1.

Web Tabanlı Dinlediğini Anlama Testinin Madde Analizleri Sonuçları.

\begin{tabular}{|c|c|c|c|c|c|}
\hline Madde & $P_{j}$ & $r_{j x}$ & Madde & $\mathbf{P}_{\mathrm{j}}$ & $r_{j x}$ \\
\hline 1 & .83 & .33 & 21 & .81 & .43 \\
\hline 2 & .53 & .33 & 22 & .52 & .48 \\
\hline 3 & .68 & .40 & 23 & .64 & .44 \\
\hline 4 & .44 & .26 & 24 & .56 & .36 \\
\hline 5 & .83 & .32 & 25 & .74 & .37 \\
\hline 6 & .84 & .35 & 26 & .61 & .24 \\
\hline 7 & .80 & .29 & 27 & .19 & .13 \\
\hline 8 & .63 & .29 & 28 & .54 & .29 \\
\hline 9 & .77 & .40 & 29 & .88 & .38 \\
\hline 10 & .75 & .40 & 30 & .74 & .30 \\
\hline 11 & .91 & .36 & 31 & .76 & .32 \\
\hline 12 & .21 & .17 & 32 & .91 & .23 \\
\hline 13 & .55 & .18 & 33 & .92 & .32 \\
\hline 14 & .25 & .13 & 34 & .84 & .34 \\
\hline 15 & .92 & .29 & 35 & .77 & .24 \\
\hline 16 & .85 & .29 & 36 & .40 & .18 \\
\hline 17 & .81 & .52 & 37 & .56 & .18 \\
\hline 18 & .68 & .48 & 38 & .60 & .21 \\
\hline 19 & .87 & .48 & 39 & .80 & .31 \\
\hline \multirow[t]{4}{*}{20} & .86 & .48 & 40 & .79 & .36 \\
\hline & & & 41 & .87 & .19 \\
\hline & & & & $\bar{P}_{j}$ & $\bar{r}_{j x}$ \\
\hline & & & & .69 & .32 \\
\hline
\end{tabular}

Web tabanlı sistem yardımıyla gerçekleştirilen bu çalışmada ulaşılan sonuçlar göz önüne alındığında, dil becerilerinin web tabanlı sistemlerin yardımıyla ölçülmesinin mümkün ve aynı doğrultuda bu tür sistemlerin uygulanabilir olduğu söylenebilir. Ortaya çıkan sonuçlar ve alan yazındaki çalışmalar incelendiğinde gelecek çalışmalar için web tabanlı sistemler yardımıyla dil becerilerinin sadece ölçme ve değerlendirme aşamasında değil, aynı zamanda dil becerilerinin kazanılması ve öğretimi süreçlerinde de web tabanlı sistemlerin kullanılabilirliği üzerinde durmakta fayda vardır. Bu araştırma sürecinde öğrencilerin dinleme esnasında daha dikkatli ve güdülenmiş oldukları gözlenmiştir. Bireyselleştirilmiş 
öğrenme, öğretme, ölçme ve değerlendirme ortamı sağlayan bu sistemler sayesinde öğrenciler, çoğu dış etkenden bağımsız olarak çalışabilmektedirler. Bu sistemlerin zaman ve mekândan bağımsız olması ve etkileşimli ortamlar sunabilmesi, öğrenmeye katkı getiren ve doğrudan derslerde kullanılabilecek hemen her konu alanına yönelik kaynak ve materyaller sağlayan bir yapı arz etmektedir (Oral, 2005). Ayrıca daha fazla görselin yer aldığı, hareketli resim veya videoların yer aldığı ortamlara ve farklı medya uygulamalarına da imkân tanımaktadır. Bu çerçevede dinleme becerisine yönelik web tabanlı hazırlanan ortamlarda yürütülen uygulamaya dayalı çalışmalar ve bununla ilgili kuramsal çalışmalar, web tabanlı ortamların kullanılabilirliğini göstermektedir (Akbaba, 2009; Chalhoub-Deville, 2001; Chen ve Zhang, 2011; Hoven, 1999; Pala, 2005; Pardo-Ballester, 2008; Roever, 2001; Shin, 2008; Wang, 2006; Wang, 2010).

Dinleme becerisinin ülkemizde ve dünyada önemi son yıllarda fark edilmiş olması, eğitimi ve akademik çalışma alanı açısından eksikliklere yol açmıştır. Özellikle Türkçenin ana dili olarak öğretilmesi ve becerilerinin geliştirilmesi sürecinde dinleme becerisi, dikkate alınmamıştır. Bunun sonucunda öğrencilerin dinleme becerisi açııından ne düzeyde olduklarını belirleyebilecek standart testlere ve gelişen teknolojiler bağlamında web tabanlı ortamlarda geliştirilmiş sistemlere ihtiyaç duyulmaktadır. Bundan dolayı ilköğretim 5. Sınıf Türkçe Dersi Öğretim Programı dinleme kazanımları bağlamında hazırlanan bu testin, gerçekleştirilen analizler sonucunda kullanılabilir niteliklere sahip olduğunu göstermektedir. Bunun yanında 2012-2013 öğretim yılından itibaren Milli Eğitim Bakanlı̆ı tarafından uygulamaya konulması düşünülen "Fırsatları Artırma ve Teknolojiyi İyileştirme Hareketi (FATiH)" projesi (http://fatihprojesi.meb.gov.tr/tr/index.php) dâhilinde bu tür ortamların yaygınlaştırılması, ana dili ve yabancı dil derslerinin daha etkili bir şekilde geçmesine imkân tanınmış olacaktır.

Elde edilen sonuçlar ışığında şu öneriler sunulabilir:

- Okulların teknik ve teknolojik (bilgisayar, internet) altyapısının geliştirilmelidir.

-Web tabanlı sistemlerin öğrencilerin motivasyonu üzerindeki etkisi araştırılmalıdır.

- Dinleme becerilerinin geleneksel ve web tabanlı şekilde ölçülmesi üzerine karşılaştırmalı çalışmalar yapılmalıdır.

- Temel dil becerilerinin web tabanlı sistemler yardımıyla ölçülmesi üzerine çalışmalar yapılmalıdır.

- Diğer dersler için web tabanlı ölçme ve değerlendirme sistemleri geliştirilip yaygınlaştırılmalıdır.

\section{Kaynakça}

Akbaba, B. (2009). Atatürk Ilkeleri ve Inkılâp Tarihi öğretiminde çoklu ortam kullanımının akademik başarı ve tutumlara etkisi. Yayımlanmamış Doktora Tezi. Gazi Üniversitesi, Ankara.

Al-Amri, S. (2008). Computer-based testing vs. paper-based testing: A comprehensive approach to examining the comparability of testing modes. Essex Graduate Student Papers in Language \& Linguistics, 10, 22-44.

Alderson, J. C. (2000). Technology in testing: The present and the future. System, 28, 593-603.

Aybek, E. C. (2012). Kâğıt - kalem formu ve bilgisayar ortamında uygulanan genel yetenek testinin psikometrik özelliklerinin karşılaştırılması. Yayımlanmamış Yüksek Lisans Tezi. Ankara Üniversitesi, Ankara.

Bahar, M., Nartgün, Z., Durmuş, S. ve Bıçak, B. (2010). Ölçme ve değerlendirme teknikleri-Öğretmen el kitabı. Ankara: Pegem Akademi.

Boo, J. (1997). Computerized versus paper-and-pencil assessment of educational development: Score comparability and examinee preferences. Unpublished PhD Dissertation, University of lowa.

Brown, J. D. (1997). Computers in language testing: Present research and some future directions. Language Learning \& Technology, 1(1), 44-59. http://lt.msu.edu/vol1num1/brown/default.html internet adresinden 17.08.2011 tarihinde edinilmiştir. 
Bugbee, A. (1996) The equivalence of paper-and-pencil and computer-based testing. Journal of Research on Computing in Education, 28(3), 282-300.

Büyüköztürk, Ş. (2010). Sosyal bilimler için veri analizi el kitabı. Ankara: Pegem Akademi.

Büyüköztürk, Ş., Kılıç Çakmak, E., Akgün, Ö. E., Karadeniz, Ş. ve Demirel, F. (2010). Bilimsel araştırma yöntemleri. Ankara: Pegem Akademi.

Chalhoub-Deville, M. (2001). Language testing and technology: past and future. Language learning \& technology, 5(2), 95-98. http://ltt.msu.edu/vol5num2/deville/default.html internet adresinden 15.06.2012 tarihinde edinilmiştir.

Chalhoub-Deville, M. ve Deville, C. (1999). Computer adaptive testing in second language contexts. Annual Review of Applied Linguistics, 19, 273-299.

Chen, L. ve Zhang, R. (2011). Web-based CALL to listening comprehension. Current Issues in Education, 13(4). http://cie.asu.edu/ojs/index.php/cieatasu/article/view/286 internet adresinden 11.06 .2012 tarihinde edinilmiştir.

Choi, I., Kim, K. ve Boo, J. (2003) Comparability of a paper-based language test and a computer-based language test. Language Testing, 20(3), 295-320.

Çifçi, M. (2006). Türkçe öğretiminin sorunları. G. Gülsevin ve E. Boz, (Ed.), Türkçenin çağdaşs sorunları içinde (77-134). Ankara: Gazi.

Ergün, E. (2002). Üniversite öğrencilerinin bilgisayar destekli ölçmeden elde ettikleri başarının kalemkâğıt testi başarısı, bilgisayar kaygısı ve bilgisayar tecrübeleri açısından incelenmesi. Yayımlanmamış yüksek lisans tezi. Anadolu Üniversitesi, Eskişehir.

Erkuş, A. (2009). Psikometri üzerine yazılar. Ankara: Türk Psikologlar Derneği Yayınları.

Giri, R. A. (1998). Listening skills for young learners. Journal of Nelta, 3(1-2), 1-5.

Gül, i. (1998). illköğretim okullarında Türkçe öğretimi. Samsun: Sönmez Ofset.

Hoven, D. (1999). A model for listening and viewing comprehension in multimedia environments. Language Learning and Technology, 3(1), 88-103. http://llt.msu.edu/vol3num1/hoven/index.html internet adresinden 19.06.2012 tarihinde edinilmiştir.

Johnson, N. ve Green, S. (2004). On-line assessment: The impact of mode on students' performance. The British Educational Research Association Annual Conference, Manchester, UK.

Karasar, N. (2009). Bilimsel araştırma yöntemi. Ankara: Nobel Yayın Dağııım.

Kavaliauskienè, G. (2008). Podcasting: a tool for improving listening skills. Teaching English with technology: A Journal for Teachers of English, 3(4), http://www.iatefl.org.pl/call/j_techie33.htm.

Mead, A. D., ve Drasgow, F. (1993). Equivalence of computerized and paper and-pencil cognitive ability tests: a meta-analysis. Psychological Bulletin, 114(3), 449-458.

MEB (2005). Ilköğretim Türkçe dersi öğretim programı ve kılavuzu (1-5.sınıflar). Ankara: MEB.

Oral, B. (2005). İnternet ve eğitim. A. Tarcan, (Ed.), Internet ve toplum içinde (90-116). Ankara: Anı.

Özbay, M. (2010). Anlama teknikleri II: Dinleme eğitimi. Ankara: Öncü.

Özçelik, D. (2010). Test hazırlama kılavuzu. Ankara: Pegem Akademi.

Özçelik, D. (2011). Ölçme ve Değerlendirme. Ankara: Pegem Akademi.

Pala, O. (2005). Teaching listening and reading comprehension in Turkish using web-based materials. The Final Project, University of Oregon. 
http://citeseerx.ist.psu.edu/viewdoc/download?doi=10.1.1.124.8608\&rep=rep1\&type=pdf internet adresinden 11.06.2012 tarihinde edinilmiştir.

Pardo-Ballester, C. (2008). The construct validity of a web-based listening comprehension exam. C. A. Chapelle, Y. R. Chung ve J. Xu (Eds.), In Towards adaptive CALL: Natural language processing for diagnostic language assessment,(209-227). Ames, IA: lowa State University.

Programme for International Student Assessment (2010). PISA computer-based assessment of student skills in science. OECD Publications.

Pomplun, M., Frey, S. ve Becker, D. (2002). The score equivalence of paper-and-pencil and computerized versions of a speeded test of reading comprehension. Educational and Psychological Measurement, 62(2), 337-354.

Roever, C. (2001). Web-based language testing. Language Learning \& Technology, 5(2), 84-94. http://lt.msu.edu/vol5num2/roever/default.html internet adresinden 06.06.2012 tarihinde edinilmiştir.

Sawaki, Y. (2001) Comparability of conventional and computerized tests of reading in a second language. Language Learning \& Technology, 5(2), 38-59.

Shin, S. Y. (2008). Examining the construct validity of a web-based academic listening test: an investigation of the effects of response formats. The Spaan Fellowship Working Papers in Second or Foreign Language, 6, 95-129. English Language Institute. University of Michigan. http://www.cambridgemichigan.org/sites/default/files/resources/SpaanPapers/Spaan V6 Shin.pdf internet adresinden 18.06.2012 tarihinde edinilmiştir.

Smith, B., Caputi, P. ve Rawstorne, P. (2000). Differentiating computer experience and attitudes toward computers: an empirical investigation. Computers in Human Behavior, 16, 59-81.

Wang, X. (2006). Evaluating a web-based listening programme for Chinese University non-English majors. US-China Education Review, 3(5), 74-76.

Wang, Y. (2010). To give control to learners or not? A comparative study of two ways of teaching listening. English Language Teaching, 3(2), 162-174.

Whitworth, B. (2001). Equivalency of paper-and-pencil tests and computer-administered tests. Unpublished PhD dissertation, University of North Texas.

Yangın, B. (1999). Ilköğretimde etkili öğretme ve öğrenme öğretmen el kitabı modül 4, ilköğretimde Türkçe öğretimi. Ankara: Milli Eğitim Bakanlığı.

\section{Ekler}

Ek 1.

Pin Kodu Ile Sisteme Giriş Sayfası.

Dinlediğini Anlama Testi

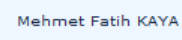

Bu ankete erişim sınırlanmış olduğundan, katılıak için bir pin koduna sahip olmalısınız.

Eğer size bir pin kodu verilmişse lütfen aşağıdaki kutuya yazın ve Devam düğmesine tiklayin.

Pin kodu

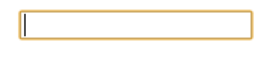


Ek 2.

Sistem Uyarısı.

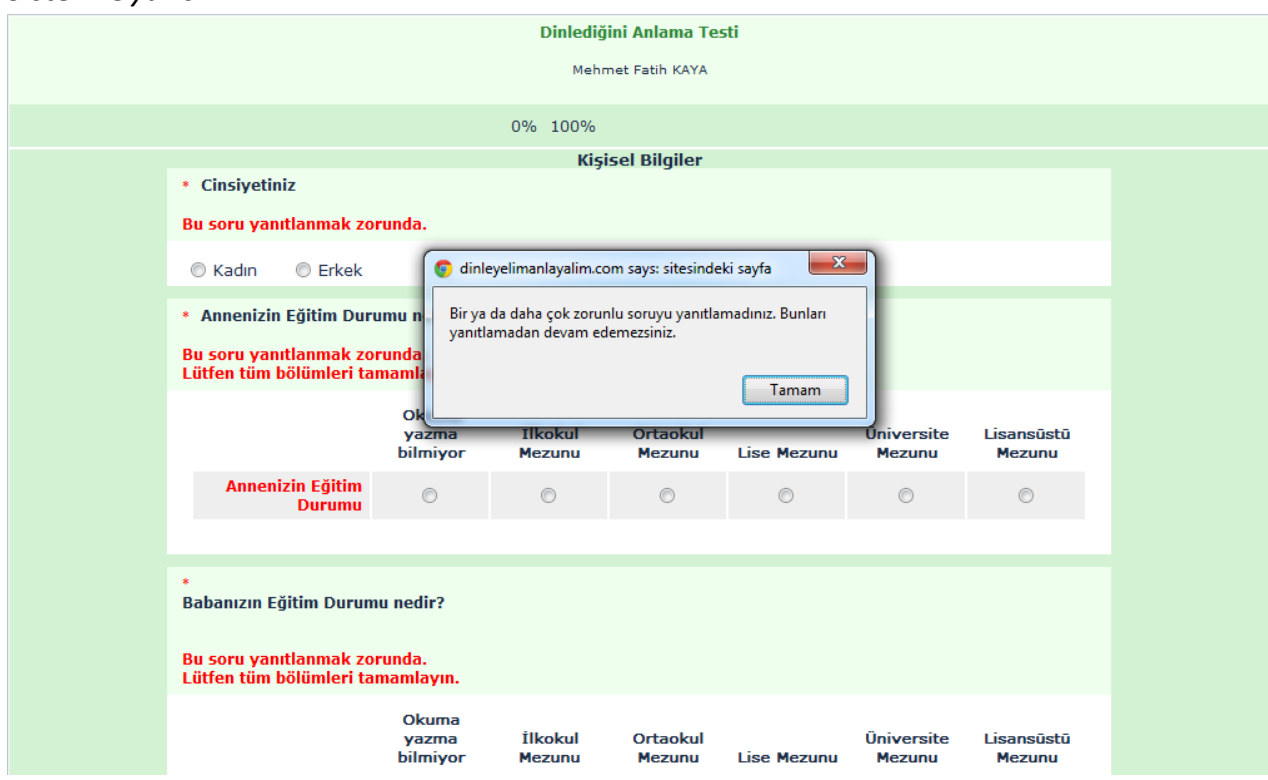

Ek 3.

Çoktan Seçmeli Soru Örneği.

*

Dinlediğiniz parçaya göre çiftçi neden oğullarından çubukları kırmalarını istemiştir?
Aşağıdaki yanıtlardan birini seçin
Onlara sevgiyi anlatmak
Onları sevdiğini göstermek
Onlara bir ders vermek
Neden kavga ettiklerini anlamak

Dinlediğiniz parçada aşağıdaki sorulardan hangisinin cevabı vardır?

\section{Aşağıdaki yanıtlardan birini seçin}

Çiftçinin oğulları birbirlerini neden sevmiyorlar?

çiftçinin oğulları kavga etmeyi bıraktılar mı?

çiftçi, oğullarının kavgalarını nasıl bitirdi?

Düşmanlar, çiftçinin oğullarını neden kavga ettiriyorlar?

- Aşağıdaki atasözlerinden hangisi, dinlediğiniz parçanın ana düşüncesini anlatır? Aşağıdaki yanıtlardan birini seçin
Ne ekersen onu biçersin
İki karpuz bir koltuğa sığmaz
- Bir elin nesi var, iki elin sesi var
O Ne verirsen elinle o da gelir seninle

ere Kaydet Sonraki $\gg$


Ek 4.

Çoklu Seçmeli Soru Örneği.

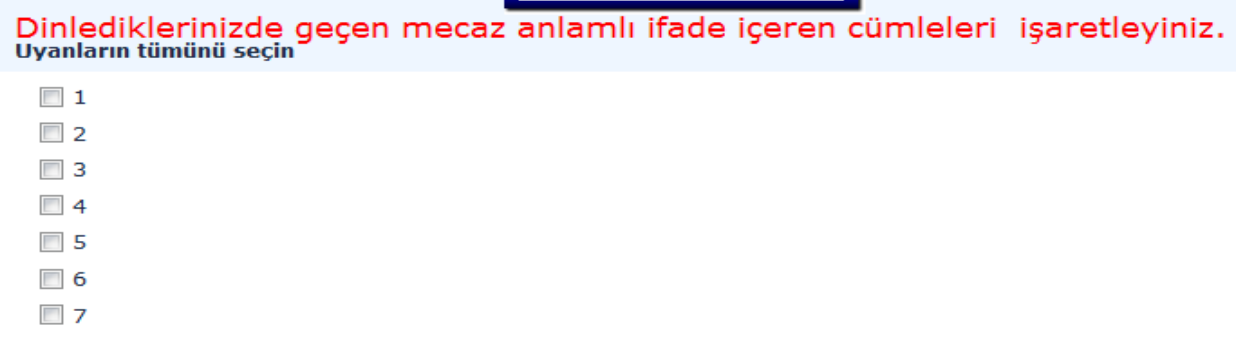

Ek 5.

Boşluk Doldurma Soru Örneği.
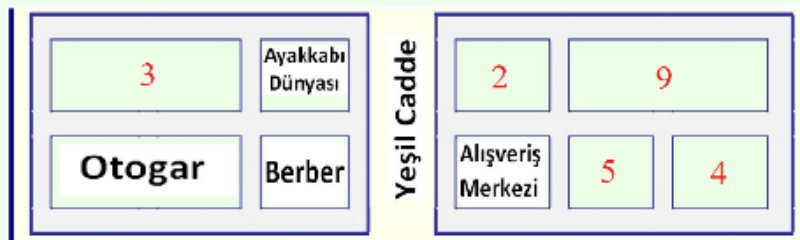

Birinci Bulva

Birinci Bulvar
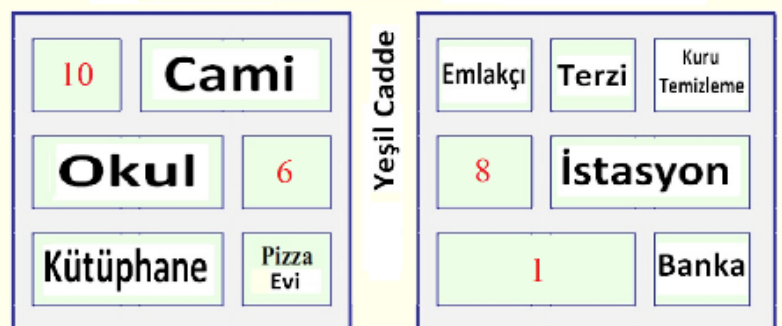

ikinci Bulvar

Necmi Bakkal Kitapçı

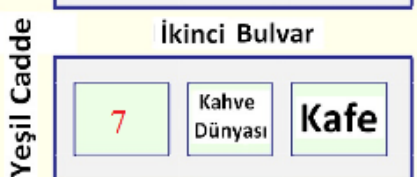

-10 saniye aralıkla cüm/eler dinleveceksiniz.

Söylenen yerlerin hangi numaralar olduğunu karşısına yazınız.

Bu alanlara yalnız sayılar yazılabilir

Belediye

Jimnastik Salonu

Lokanta

Çiçekçi

Kaya Tantuni

Postane

Ekmek Fırını

Sağlık Ocağı 